\title{
Pathogenicity of Aspergillus spp. Isolates Originating from Serbia
}

\author{
Milica Nikolić* · Iva Savić · Slavica Stanković
}

Maize Research Institute "Zemun Polje", Slobodana Bajića 1,11185 Belgrade, Serbia

\begin{abstract}
Summary: Species of the genus Aspergillus, section Flavi are facultative plant pathogens with the capability to contaminate primary agricultural products in the field, at harvest, in warehouses, and during processing. Infection is done through silk or injuries on maize ears. The objective of this study was to test pathogenicity of $25 \mathrm{~A}$. parasiticus isolates on barley leaves. A. parasiticus was isolated from maize kernels collected from 22 locations in Serbia during 2013-2015. Inoculation of the first barley leaf was done by the spore suspension of the fungus $A$. parasiticus. The spot sizes were statistically compared and this comparison showed that the isolate MRIZP 3930 was the least virulent. The isolate MRIZP 3819 was the most virulent seven days after inoculation and together with the isolate MRIZP 4265 was classified into the most aggressive group rated as 5. Pathogenicity was confirmed in all isolates.

Key words: Aspergillus, barley, inoculation, maize, pathogens, virulence
\end{abstract}

\section{Introduction}

Species of the genus Aspergillus, section Flavi, are worldwide distributed in nature. Aspergillus flavus (Link ex Fr.) is a facultative plant pathogen with a capacity to colonise a significant number of plant species including maize, cottonseed, earth nut, and many other crops (Diener et al., 1987). These species are usually isolated from soil, feed, stored grain, and different types of food as well. They contribute to the process of degradation and some of them, A. flavus and A. parasiticus Speare, are pathogens to vertebrates, including man (Raper \& Fennell, 1965).

A. flavus and $A$. parasiticus are related fungi that may contaminate primary agricultural products in the field, at harvest, in storages and during processing (Diener et al., 1987). Infection is done through silk or injuries on the maize ear. Conidia germinate on silk and a formed mycelium further penetrates alongside the ear, colonising palea and leaf area, rarely the cob. The presence of fungi on the grain surface provides the rapid colonisation of the ear after tissues are mechanically damaged (Marić et al., 2002).

Beside direct losses from infections of maize kernels, $A$. parasiticus produces aflatoxins, which are the most important group of mycotoxins considering their effects on health of people and animals (Bennett \&

Corresponding author:

mnikolic@mrizp.rs

Acknowledgement:

This study is a part of the project TR 31023 financed by the Ministry of Education, Science, and Technological Development of the Republic of Serbia.
Klich, 2003). Due to extremely harmful effects of these mycotoxins, their amounts are legally regulated in food and food products in Europe and Serbia (Kos, 2015).

Species of the genus Aspergillus, section Flavi, are widely spread in the regions with tropical and subtropical climate (Raper \& Fennell, 1965). Infection of cereal crops by species of the genus Aspergillus is mild under climatic conditions prevailing in the European countries: Austria (Öhlinger et al., 2004), Belgium (Chandelier et al., 2004), Germany (Curtui et al., 2004), Hungary (Varga et al., 2004), Poland (Perkowski et al., 2004), Romania (Ittu et al., 2004), UK (Scudamore, 2004), etc. In recent years, climatic changes have favoured extraordinary high intensity occurrence of pathogenic and toxigenic species of the genus Aspergillus under Serbian agroecological conditions during the maize growing season (Nikolić et al., 2015). High temperatures as well as high relative humidity of air are necessary for the occurrence and the intensive development of maize ear aspergillosis under field conditions.

In the world, there is little information concerning the manifestation of pathogenicity of Aspergillus spp. that originate from various hosts. According to studies carried out by Raymond et al. (2000) the pathogenicity of Aspergillus flavus isolates in the USA has been confirmed on French bean leaves under in vitro conditions.

In Serbia, A. parasiticus was for the first time isolated form maize grain during the growing season of 2012 (Stanković et al., 2015). That is way there is not enough information on the distribution, economic damages and toxigenic potential of this species isolates 
Table 1. Survey of $A$. parasiticus isolates over locations and years of isolation

\begin{tabular}{|c|c|c|}
\hline $\begin{array}{l}\text { Designation of isolates } \\
\text { in MRIZP collection }\end{array}$ & Location & $\begin{array}{l}\text { Year of } \\
\text { isolation }\end{array}$ \\
\hline 3802 & Slatina (Podrinje) & 2013 \\
\hline 3808 & Zminjak (Mačva) & 2013 \\
\hline 3812 & Lozničko Polje & 2013 \\
\hline 3817 & Valjevska Loznica & 2013 \\
\hline 3819 & Valjevska Loznica & 2013 \\
\hline 3822 & Stublenica & 2013 \\
\hline 3930 & Južni Banat & 2013 \\
\hline 3937 & Orlovat & 2013 \\
\hline 3977 & Radojevo & 2013 \\
\hline 3990 & Ostojićevo & 2013 \\
\hline 4008 & Zemun Polje & 2013 \\
\hline 4045 & Bajmok & 2013 \\
\hline 4194 & Velika Plana & 2015 \\
\hline 4195 & Zemun Polje & 2013 \\
\hline 4196 & Sakule & 2015 \\
\hline 4232 & Debeljača & 2015 \\
\hline 4239 & Feketić & 2015 \\
\hline 4250 & Počekovina & 2015 \\
\hline 4254 & Mramorak & 2015 \\
\hline 4255 & Kikinda & 2015 \\
\hline 4259 & Gakovo & 2015 \\
\hline 4260 & Žarkovac & 2015 \\
\hline 4262 & Apatin & 2015 \\
\hline 4263 & Pančevo & 2015 \\
\hline 4265 & Medveđa & 2014 \\
\hline 4268 & Medveđa & 2015 \\
\hline
\end{tabular}

Pathogenicity of observed isolates was checked by the method described by Imanthiu et al. (2009).

in Serbia. Recent studies have been related to the identification of this species on the basis of morphological and molecular traits (Khoury et al., 2011).

Due to economic damages on maize grain caused by $A$. parasiticus as well as due to potential contamination by aflatoxins, the aim of the present study was to analyse the pathogenicity potential of $A$. parasiticus isolates originated from Serbia.

\section{Materials and Methods}

A. parasiticus cultures were isolated from samples maize kernels collected in 22 locations in Serbia from 2013 to 2015 (Table 1). Selected 25 A. parasiticus isolates and one $A$. flavus isolate (used as a positive control), were purified to monospore culture and conserved in the Maize Research Institute collection in the refrigerator at the temperature of $+4^{\circ} \mathrm{C}$. In order to maintain these isolates in the collection, monospore cultures were subcultured on the three nutritive media: PDA (potato dextrose agar), CLA (carnation leaf agar) and SNA (synthetic nutrient-poor agar). The composition and preparation of PDA and CLA were described by Burgess et al. (1994), while SNA was described by Nirenberg (1976).

\section{Preparation of barley leaves}

Surface sterilised seeds of winter barley cultivar Nektar were sown in the pot $(27 \mathrm{~cm} \times 15 \mathrm{~cm})$ and grown in the growth chamber at $20^{\circ} \mathrm{C}$ under $12-\mathrm{h}$ photoperiod. In case of need, plants were watered. The virulence test of $25 \mathrm{~A}$. parasiticus isolates was performed on the first barley leaf, which was cut, prior to inoculation, sprayed with a $70 \%$ ethanol solution, dried and placed into Petri dishes with wet filter paper $(2 \mathrm{ml}$ of sterile distilled water/Petri dish).

\section{Preparation of spore suspension}

A. parasiticus isolates were cultured on potato dextrose agar (PDA) at the temperature of $25^{\circ} \mathrm{C}$ in the dark. The 7-day-old cultures were used for the preparation of the spore suspension by adding $10 \mathrm{ml}$ sterile distilled water with $0.01 \%$ Tween 20 . The suspension concentration was adjusted by the haemocytometer to approximately $3 \times 10^{7}$ spores $\mathrm{ml}^{-1}$.

\section{Inoculation and incubation}

An injury on each leaf was made by a pipette tip immediately prior to inoculation. This method was used to inoculate the first barley leaf with the spore suspension of the fungus $A$. parasiticus by adding $10 \mu \mathrm{l}$ suspension of the concentration of $3 \times 10^{7}$ spores $\mathrm{ml}^{-1}$ with Tween 20. Control leaves were inoculated by applying the equal amount of sterile distilled water. Eight leaves in four replicates were inoculated with such prepared conidial suspension (total of 32 leaves per isolate) and were incubated at $27 \pm 0.5^{\circ} \mathrm{C}$. In order to provide conditions of higher humidity, water was added if it was necessary. Syndrome occurrence and disease intensity were observed each day, and after 3, 5 and 7 days rating was done on the 1-5-scale: no symptoms (1), $0.5-\mathrm{mm}$ spots around the inoculation site (2), $1-\mathrm{mm}$ chlorotic spots (3), the beginning of necrosis, $1.5-\mathrm{mm}$ spots (4) and necrosis followed by the occurrence of aerial mycelia (5) (Figure 1). The pathogen was reisolated from the plant with the aim to confirm Koch's postulates.

\section{Results}

Virulence of $25 \mathrm{~A}$. parasiticus isolates, collected in fields and warehouses in locations throughout Serbia during the past three years was observed in this study.

Tested $A$. parasiticus isolates caused the occurrence of irregularly shaped spots on barley leaves. The first symptoms occurred two days after inoculation in the form of interval chlorosis accompanied with leaf 


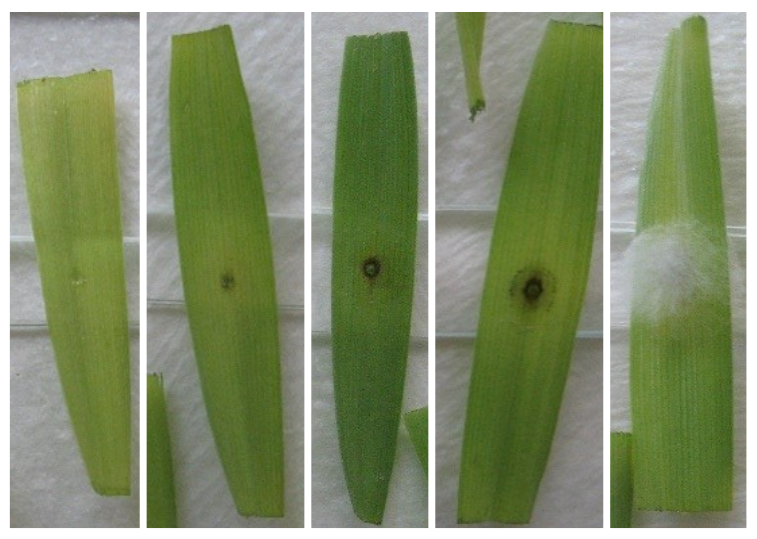

Figure 1. Occurrence of brown spots on leaves of barley cultivar Nektar inoculated by $A$. parasiticus isolates seven days after inoculation: control, MRIZP 3802, MRIZP 3812, MRIZP 3808 and MRIZP 3819 (from left to the right).

colouring. Five days after inoculation, the most aggressive strains sporulated on the surface of leaves. The occurrence of the mycelium was observed in certain isolates on the lower surface of leaves. There were no symptoms on control leaves.

\section{Discussion}

Aspergillus spp. is regarded as an opportunistic pathogen that penetrates through injuries or colonise an attenuated tissue (Raper \& Fennell, 1965). Species of the genus Aspergillus were isolated from both freshly harvested maize and maize after harvest. These species can penetrate through silk and injuries on maize ears. Infection occurs at high temperatures and high air humidity (Marić et al., 2002). Virulence of isolates of this fungus is reflected through their capability to overcome defence responses of host plants, to infect and colonise the plant tissue.

Spots were observed for seven days, and it was noticed that the longer incubation was the greater spots were noticed in all tested isolates. The statistical comparison of obtained spot sizes on barley leaves showed that some isolates differed from remaining in all readings. Hence, the least virulent isolate MRIZP 3930 caused the occurrence of the smallest spots in all readings. Isolates MRIZP 3812, MRIZP 3822, MRIZP 4045, MRIZP 4194, MRIZP 4195, MRIZP 4239, MRIZP 4255, MRIZP 4259, MRIZP 4263, and MRIZP 4268 were in the group of moderate virulent isolates. The isolate MRIZP 3819 was the most virulent after 7day inoculation, and together with the isolate MRIZP 4265 was classified into group rated 5 (Table 2). At the end of studying, the highest number of isolates was rated 3 , while the lowest number of isolates were rated 5 (Figure 2).

In India, the pathogenicity test of the species $A$. terreus Thom was performed on potato leaves by the inoculum application method using hand sprayer (Louis et al., 2013). According to these authors, symptoms were mainly developed alongside the midrib. Infected leaves were yellow in the advance stage of the disease. This method was also used by Iranian scientists who isolated species A. niger (Fr.) P. Karst from ginger leaves and tested pathogenicity (Pawar et al., 2008). In addition to described methods, in the USA, pathogenicity has been tested on French bean leaves by the inoculum injection into the midrib (Leger et al., 2000). According to results obtained by these authors, symptoms started to occur two days after inoculation. Initially, symptoms occurred around the injury, and then they spread over healthy tissue. The most aggressive strains sporulated on leaves on the fifth day after inoculation. According to our

Table 2. Spot rating of inoculated leaves of barely cultivar Nektar seven days after inoculation by $A$. parasiticus isolates

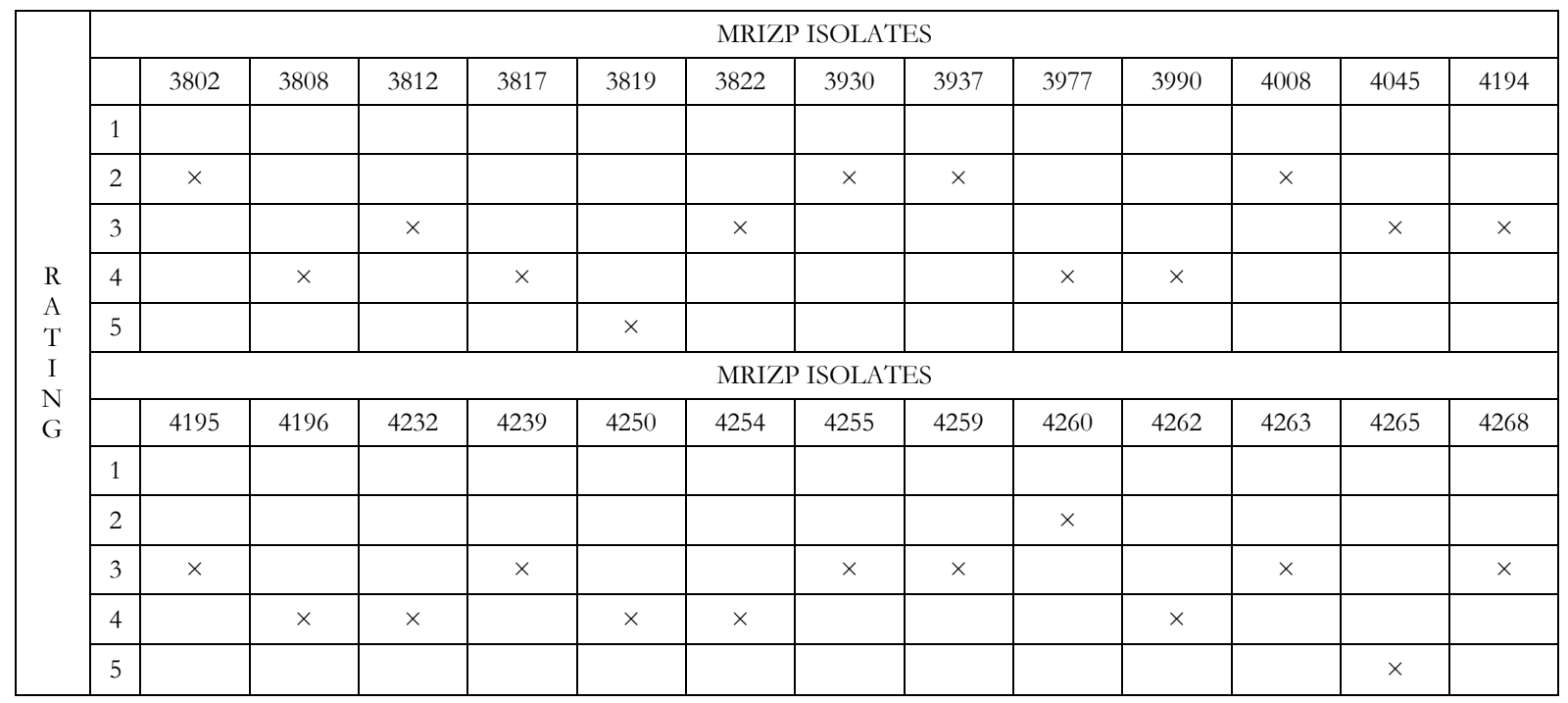




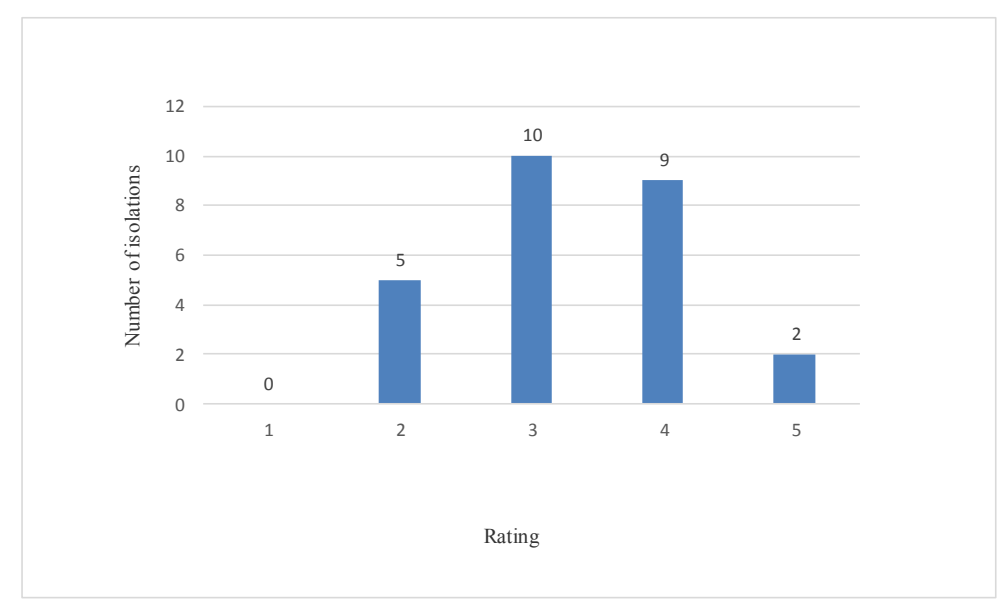

Figure 2. Virulence of $A$. parasiticus isolates on leaves of barley cultivar Nektar

results, the first symptoms occurred after two days, and leaf colouring and mycelium formation occurred in the most aggressive strains.

All observed isolates of the fungus $A$. parasiticus previously detected on maize, expressed pathogenicity to barley leaves. This danger would be even more certain if global climate changes continue and thus provide the development of this pathogen.

Since the study was carried out in the laboratory under controlled conditions, further studies should be aimed at testing pathogenicity in fields as such tests could confirm or correct already obtained results.

\section{References}

Bennett, J. W., \& Klich, M. A. (2003). Mycotoxins. Clin. Microbiol. Rev. 16, 497-516, doi: 10.1128/CMR.16.3.497-516.2003.

Burgess, L. W., Summerell, B. A., Bullock, S., Gott, K. P., \& Backhouse, D. (1994). Laboratory Manual for Fusarium Research. Sydney: University of Sydney and Royal Botanic Gardens.

Chandelier, A., Michelt, J. Z., Tangni, E. K., Baert, K., Moons, E., \& Vinkx, C. (2004). Mycotoxins survey in Belgium and toxic Fusarium in Belgian wheat. In: A. Logrieco \& A. Visconti (Eds.), An Overview on Toxigenic Fungi and Mycotoxins in Europe (pp. 11-32). Dordrecht, Boston, London: Kluwer Academic Publishers.

Curtui, V., Seidler, C., Schneider, E., \& Usleber, E. (2004). Mycotoxins in food in Germany. In: A. Logrieco \& A. Visconti (Eds.), An Overview on Toxigenic Fungi and Mycotoxins in Europe (pp. 109-121). Dordrecht, Boston, London: Kluwer Academic Publishers.

Diener, U. L., Cole, R. J., Sanders, T. H., Payne, G. A., Lee, L. S., \& Klich, M. A. (1987). Epidemiology of aflatoxin formation by Aspergillus flavus. Annual Review of Phytopathology, 25, 249-270.

Imanthiu, S. M., Ray, R. V., Back, M., Hare, M. C., \& Edwards, S. G. (2009). Fusarium langsethiae pathogenicity and aggressiveness towards oats and wheat in wounded and unwounded in vitro detached leaf assays. European Journal of Plant Pathology, 124, 117126.

Ittu, M., Trif, A., \& Belc, N. (2004). Toxigenic fungi and mycotoxins in Romania: challenges and approaches. In: A. Logrieco \& A. Visconti (Eds.), An Overview of Toxigenic Fungi and Mycotoxins in Europe (pp. 185-194). Dordrecht, Boston, London: Kluwer Academic Publishers.

Khoury, A., Atoni, A., Rizk, T., Lteif, R., Kallasy, M. I., \& Mebrihi, A. (2011). Differentiation between Aspergillus flavus and Aspergillus parasiticus from Pure Culture and AflatoxinContaminated Grapes Using PCR-RFLP Analysis of afR-afl] Intergenic Spacer.
Kos, J. (2015). Aflatoksini: analiza pojave, procena rizika $i$ optimizacija metodologije odredivanja u kukuruzu i mleku. Doctoral dissertation. Novi Sad: University of Novi Sad, Faculty of Technology.

Leger, R., Screen, S., \& Shams-Pirzadeh, B. (2000). Lack of Host Specialization in Aspergillus flavus, Applied and Environmental Microbiology, Jan. 2000, 320-324.

Louis, B., Roy, P., Sayanika, D. W., \& Talukdar, N. C. (2013). Aspergillus terreus Thom a new pathogen that causes foliar blight of potato. Plant Pathol Quarant. 3, 29-33.

Marić, A., Ivanović, D., Lević, J., \& Penčić, V. (2002). Bolesti, štetočine i korovi kukuruza i njihovo suzbijanje. Beograd-Zemun: Institut za kukuruz "Zemun Polje”, Novi Sad: Školska knjiga.

Nikolić, M., Savić, I., Stanković, S., Vico, I., \& Duduk, N. (2015). Uticaj temperature na razvoj toksigenih vrsta gljiva. VII Simpozijum sa međunarodnim ǚeš́em „Inovacije u ratarskoj i povrtarskoj proizuodnji“, 11.12.2015., Beograd.

Nirenberg, H. (1976). Untersuchungen uber die morphologische biologische Differenzierung in der Fusarium-Sektion Liseola. Berlin - Dahlam: Mittelungen aus der Biologischen Bundesanstalt fur Land - und Forstwirtschaft.

Öhlinger, R., Adler, A., Kräutler, O., \& Lew, H. (2004). Occurrence of toxigenic fungi and related mycotoxins in cereals, feeds and foods in Austria. In: A. Logrieco \& A. Visconti (Eds.), An Overview on Toxigenic Fungi and Mycotoxins in Europe (pp. 1-10). Dordrecht, Boston, London: Kluwer Academic Publishers.

Pawar, N., Patil, V., Kamble, S., \& Dixit, G. (2008). First report of Aspergillus niger as a plant pathogen on Zingiber officinale from India. Plant Disease, 92(9), 1368.

Perkowski, J., Chełkowski, J., \& Goliński, P. (2004). Occurrence of mycotoxins in cereals, plants, foods and feeds in Poland. In: A. Logrieco \& A. Visconti (Eds.), An Overview on Toxigenic Fungi and Mycotoxins in Europe (pp. 161-172). Dordrecht, Boston, London: Kluwer Academic Publishers.

Raper, K. B., \& Fennell, D. I. (1965). The Genus Aspergillus. United States of America: Robert E. Krieger Publishing Company Inc.

Scudamore, K. A. (2004). Occurrence of mycotoxins in UK food commodities. In: A. Logrieco \& A. Visconti (Eds.), An Overview on Toxigenic Fungi and Mycotoxins in Europe (pp. 247-252). Dordrecht, Boston, London: Kluwer Academic Publishers.

Stanković, S., Lević, J., Nikolić, M., Krnjaja, V., \& Jauković, M. (2015). Prvi nalaz Aspergillus parasiticus u proizvodnji kukuruza u Srbiji. Savetovanje o zaśtiti bilja, Zlatibor 23-27.11.2015., pp. 32-33.

Varga, J., Tóth, B., Mesterházy, Á., Téren, J., \& Fazekas, B. (2004). Mycotoxigenic fungi and mycotoxins in foods and feeds in Hungary. In: A. Logrieco \& A. Visconti (Eds.), An Overview on Toxigenic Fungi and Mycotoxins in Europe (pp. 123-139). Dordrecht, Boston, London: Kluwer Academic Publishers. 


\section{Patogenost izolata Aspergillus spp. poreklom iz Srbije}

\section{Milica Nikolić · Iva Savić · Slavica Stanković}

Sažetak: Vrste roda Aspergillus sekcije Flavi su fakultativni biljni patogeni, čija se sposobnost ogleda u kontaminaciji primarnih poljoprivrednih proizvoda u polju, tokom berbe, u skladištu i tokom procesa prerade. Infekcija se obavlja preko svile ili oštećenja na klipu kukuruza. Cilj ovog rada bio je da se oceni patogenost 25 izolata $A$. parasiticus na listovima ječma. Kulture $A$. parasiticus su izolovane iz uzoraka zrna kukuruza koji su prikupljani sa 22 lokaliteta u Srbiji u periodu 2013-2015. godina. Inokulacija prvog lista ječma izvršena je pomoću suspenzije spora gljive $A$. parasiticus. Statističkim poređenjem dobijenih vrednosti veličina pega, pokazano je da je najmanje virulentan izolat MRIZP 3930. Izolat MRIZP 3819 se izvojio kao najvirulentniji posle 7 dana inokulacije, a zajedno s izolatom MRIZP 4265 je svrstan u najagresivniju grupu koja je kategorisana ocenom 5. Svi ispitivani izolati su potvrdili patogenost.

Ključne reči: Aspergillus, inokulacija, ječam, kukuruz, patogeni, virulentnost 